UDC 332:631.1

(C) 2019

\title{
Institutional levers of maintenance of ecological-economic efficiency of agricultural land-use
}

\author{
Butrym O. ${ }^{1}$, Doroschuk V. ${ }^{2}$, Komarova N. ${ }^{3}$, Tereschenko Yu. ${ }^{4}$ \\ Institute of agroecology and natural management of NAAS, Metrolohichna Str., 12, Kyiv, 03143, Ukraine;

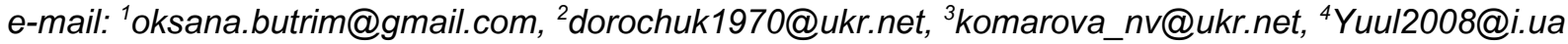

\section{Institutional levers of maintenance of ecological-economic efficiency of agricultural land-use}

The purpose. To carry out ecological-economic assessment of efficiency of use of land resources of agricultural purpose in Kyiv oblast in comparison with state of ecological-economic efficiency of land-use at national level and to offer institutional levers of maintenance of its efficiency. Methods. By means of system analysis and synthesis with engaging statistical and correlation analysis with the subsequent demonstration of results and application of graphical method ecological-economic assessment of differences of level of efficiency of use of agrilands in Kyiv oblast from its state at national level is made. On the basis of monographic method generalization of experience of researches of domestic schools of pedology, agroecology is carried out. That may become a basis of the offered directions of institutional improvement of ways of overcoming ecological-economic crisis of agricultural land-use. Results. It is determined that modern organizational-economic approaches to agricultural land-use in Ukraine do not provide its balanced state. Conceptual aspects of maintenance of admissible level agroecological safety of agricultural land-use are specified at commodity production of plant growing and the role of local communities in solution of that problem in view of administrative reform of Ukraine is shown. Significance of heading free economic turnover of ground areas of agricultural purpose is underlined. Conclusions. It is proved that escalation of profits of farms leads to depletion of agricultural potential which descends now in Ukraine, and creates threats to maintenance of comprehensible level of agroecological and food safety. Significance of institutional and economic levers in innovation of organizational-economic conditions of managing is shown. These conditions are aimed at level of agrochemical parameters of qualitative state of soil covering of agrilands, that is an effective direction of maintenance of recovery and conservation of agricultural potential.

Key words: agricultural potential, land resources of agricultural purpose, commodity output of plant growing, agroecological safety, over-all performance, agricultural production, soil covering.

\section{https://doi.org/10.31073/agrovisnyk201902-09}

Problem statement. The analysis of the land-using characteristics, which is being introduced in Ukraine, and agriculture in particular, proves its unbalanced level, which is confirmed by the volume of land degradation processes. The ensuring of acceptable level of agroecological safety while preserving the tendency to increase the profits of agri-enterprises with the crop plant profile requires is prudent attitude towards the use of the basic resource potential - agricultural lands. Under the existing socialeconomical conditions and taking into account the European integration aspirations of Ukraine, the solution of these tasks require the introduction of organizational and economic reforms of the institutional component with a focus on increasing the responsibility for the qualitative characteristics of the soils, or in other words that is obligations for the state of the agrarian-resource potential of the region. It can be foreseen that the formation of the financial and economic dependence of the profit of agro-entrepreneurs should be formed not only from the volumes of harvesting and on the quality of the products, but also from the state of the soil, which is acquired due of the productive land-using [1]. The introduction of the free economic plots conversion will accelerate the implementation of this task.

The search of solutions to problems of balanced use of agricultural land and the optimal balance of land in the region are the subject of many studies. Among the national researches, the outlined range of the of issues is widely considered from a different points. In particular, the directions of the theoretical and methodological basis of organization and applied aspects of ensuring the effectiveness of land use 
were studied by I.K. Bystryakov [2], Yu.G. Ivanov, B.I. Kochurov [3], I.P. Gaydukskiy [4], P.T. Sabluk ,Yu.O. Lupenko [5], M. Stepin [6], E.V. Khlobystov [7]. Among the foreigners we can name Giacomo Grassi [8], George Boody [9], Vondracek Bruce [10], S. Shames, S. Scherr [11], A. Frelih-Larsen [12] et al.

Aspects of the formation and regulation of the market for the agricultural land use sector were studied in the works of D.S. Dobryaka [13], AG Martin [14], L.M. Granovsky [15], Yong Jiang [16] et al.

In the light of the results of the aforementioned scientists' research, there is a need to study the problem of improving the institutional system of ensuring an acceptable level of agro-ecological safety.

Goal. Conduct a comparison of the dynamics of indicators of cost and profitability of crop production products with the dynamics of qualitative indicators of agrochemical state of gross cover on agricultural lands and to offer institutional leverage to ensure an acceptable level of ecological and economic efficiency of agro-industrial processes based on the use of agricultural land.

Methods. The theoretical and methodological basis of work are general scientific and special research methods that are used for the disclosure of the approaches to the assessment of the ecological and economic efficiency of the use of agricultural land: monographic (for the generalization of national experience of soil scientists, agroecologists, which is the basis of the proposed directions of institutional improvement of ways to overcome the ecological and economic crisis of agricultural land use); graphic for visualization of analytical and statistical materials and obtained research results; economic and statistical - for qualitative and quantitative characteristics of the dynamics of infrastructure of functioning of the system of agricultural land use; system approach - to substantiate directions of improvement of the management system of the agricultural land use in conditions of market transformations; institutional - for the assessment of interrelations and research of the interactions between the subjects of agrarian activity in studying the regulatory and legal aspects of these interactions in order to ensure an acceptable level of ecological and economic efficiency of management.

Results. Production volumes over a period of time determine productivity, the growth of which depends on the characteristics of the processes of division of labor, the effectiveness of the use of resources. Agricultural production and first of all the plant growing based on the main resources that is land. The characteristics of the use of agricultural land and their agrochemical state have a direct impact on the results of production. On the other hand, the restoration and preservation of land fertility and the implementation of measures to increase it contribute to the growth of labor productivity in agroproduction. However, the level of labor productivity in Ukraine is rather low and, according to experts, industrial production is only $10 \%$ of the US labor productivity [17], but its stable growth in the agricultural sector is observed. Statistical labor productivity dynamics in agrarian economy sector in both Ukraine and the Kyiv region shows a steady increase, fig. 1. that in Ukraine by 2017 almost twice, and in the Kiev region more than 1,5 times exceeded similar indicators for crop production in 2008 [18]. 


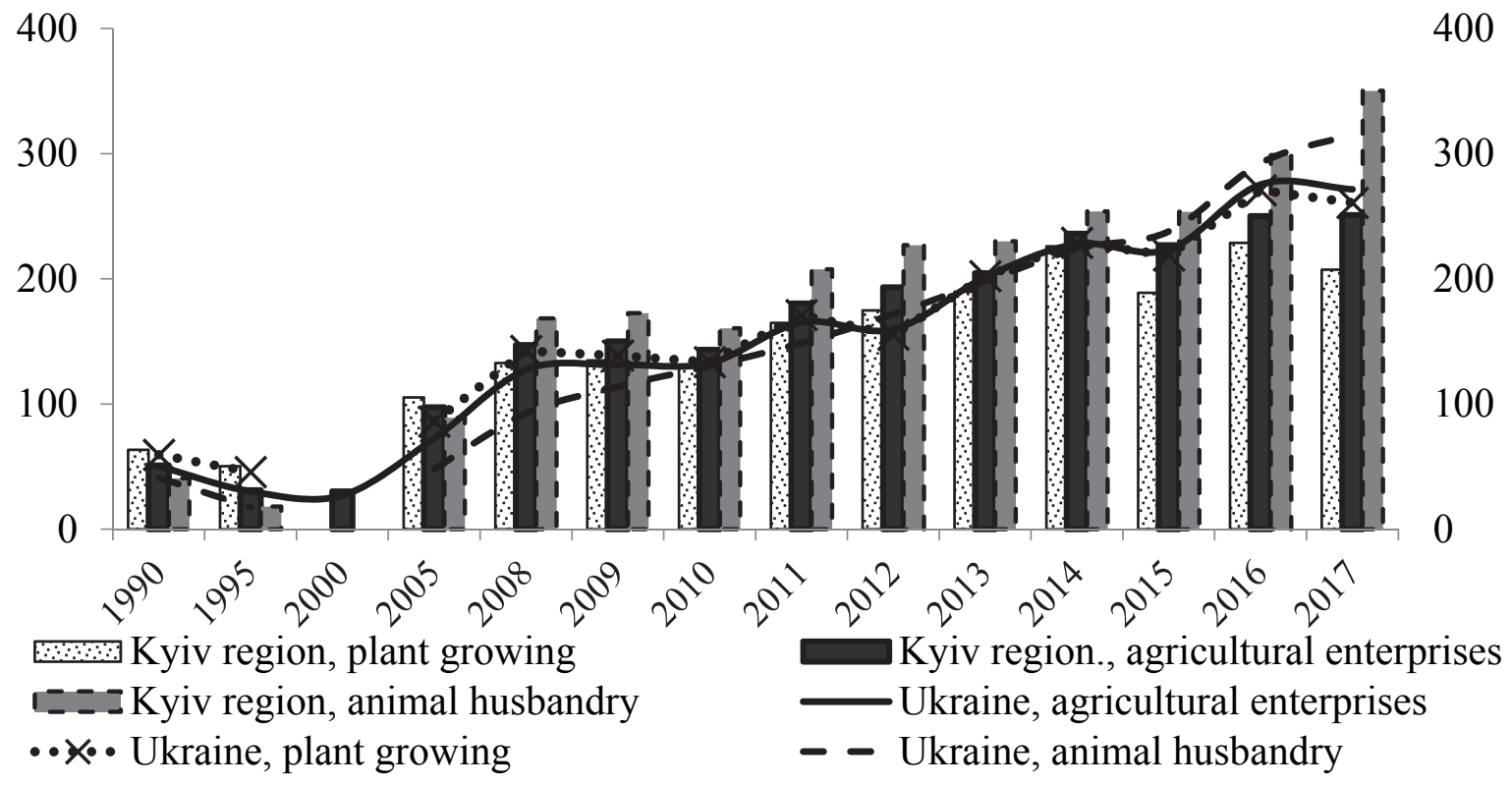

Fig. 1. Agricultural labor productivity per busy person, thousand UAH

Source: built according to [19].

Inherently, this is accompanied by an increase in the yields of the main groups of crops (Table 1) and, above all, those with high profitability indicators, for example, the profitability of grain production in Ukraine increased by almost $47 \%$ over the period of 2012-2017 [19].

At the same time there are ambiguous trends in the dynamics of arable land. In Ukraine, they increased during this period by almost 71 thousand hectares, and in the Kiev region - decreased by more than 9 thousand hectares (Fig. 2), which contributes to raising the level of anthropogenic loading on agricultural landscapes.

Table 1.

Characteristics of agricultural production in Ukraine and Kiev region.

\begin{tabular}{|c|c|c|c|c|c|c|c|c|}
\hline Characteristics & $\begin{array}{l}199 \\
0\end{array}$ & 1995 & $\begin{array}{l}200 \\
0\end{array}$ & 2005 & 2010 & $\begin{array}{l}201 \\
5\end{array}$ & 2016 & $\begin{array}{l}201 \\
7\end{array}$ \\
\hline 1 & 2 & 3 & 4 & 5 & 6 & 7 & 8 & 9 \\
\hline \begin{tabular}{l}
\multicolumn{2}{c|}{ Agricultural } \\
production in 2010 \\
prices; millions UAH: \\
- Ukraine
\end{tabular} & 145502,0 & $\begin{array}{ll}106329 \\
, 6\end{array}$ & $\begin{array}{r}928 \\
38,9\end{array}$ & $9,9^{11447}$ & 124554,1 & $\begin{array}{l}168 \\
439\end{array}$ & $\begin{array}{c}1850 \\
52,1\end{array}$ & 179474,6 \\
\hline - Kyiv region & $\begin{array}{r}692 \\
4,0\end{array}$ & $\begin{array}{r}5977, \\
9\end{array}$ & $\begin{array}{r}472 \\
2,3\end{array}$ & $\begin{array}{r}5684 \\
, 8\end{array}$ & $\begin{array}{r}6753 \\
9\end{array}$ & $\begin{array}{r}871 \\
5,6\end{array}$ & $\begin{array}{r}1034 \\
8,9\end{array}$ & $\begin{array}{r}916 \\
1,3\end{array}$ \\
\hline & Yield of agr & icultural crop & centne & s per hecté & are of the $h$ & sted a & & \\
\hline & & & & raine & & & & \\
\hline - Grain & $\begin{array}{r}35, \\
1\end{array}$ & 24,3 & 19,4 & 26,0 & 26,9 & $\begin{array}{r}41, \\
1\end{array}$ & 46,1 & $\begin{array}{r}42, \\
5\end{array}$ \\
\hline - Corn & $\begin{array}{r}38, \\
7\end{array}$ & 29,2 & 30,1 & 43,2 & 45,1 & $\begin{array}{r}57, \\
1\end{array}$ & 66 & $\begin{array}{r}55, \\
1\end{array}$ \\
\hline - Rape & $\begin{array}{r}14 \\
5\end{array}$ & 8,5 & 8,4 & 14,6 & 17,0 & $\begin{array}{r}25, \\
9\end{array}$ & 25,7 & $\begin{array}{r}27 \\
9\end{array}$ \\
\hline - Sunflower & $\begin{array}{r}15 \\
8\end{array}$ & 14,4 & 12,2 & 12,8 & 15,0 & $\begin{array}{r}21, \\
6\end{array}$ & 22,4 & $\begin{array}{r}20 \\
2\end{array}$ \\
\hline \multicolumn{9}{|c|}{ Kyiv region } \\
\hline - Grain & 35 , & 27,9 & 24,7 & 34,2 & 33,0 & 51, & 58,7 & 45 \\
\hline
\end{tabular}




\begin{tabular}{|c|c|c|c|c|c|c|c|c|}
\hline & 6 & & & & & 4 & & 6 \\
\hline - Corn & $\begin{array}{r}41, \\
7\end{array}$ & 34,4 & 43,0 & 64,8 & 54,1 & $\begin{array}{r}61, \\
9\end{array}$ & 74,1 & $\begin{array}{r}60, \\
2\end{array}$ \\
\hline - Sunflower & $\begin{array}{r}18, \\
0\end{array}$ & 9,0 & 10,0 & 16,6 & 13,5 & $\begin{array}{r}27 \\
8\end{array}$ & 25,6 & $\begin{array}{r}26, \\
5\end{array}$ \\
\hline - Rape & $\begin{array}{r}11 \\
6\end{array}$ & 9,7 & 11,7 & 13,7 & 18,4 & $\begin{array}{r}25 \\
2\end{array}$ & 27,3 & $\begin{array}{r}24, \\
1\end{array}$ \\
\hline \multicolumn{9}{|c|}{ The difference between the yields for Ukraine $(=100 \%)$ and the Kyiv region, $\%$} \\
\hline - Grain & 1,4 & 14,8 & 27,3 & 31,5 & 22,7 & $\begin{array}{r}25 \\
1\end{array}$ & 27,3 & 7,3 \\
\hline - Corn & 7,8 & 17,8 & 42,9 & 50,0 & 20,0 & 8,4 & 12,3 & 9,3 \\
\hline - Sunflower & $\begin{array}{r}23, \\
9\end{array}$ & 5,9 & 18,8 & 13,7 & $-20,6$ & 7,3 & $-0,4$ & $-5,0$ \\
\hline - Rape & $\begin{array}{r}- \\
26,6\end{array}$ & $-32,6$ & $-4,1$ & 7,0 & 22,7 & $\begin{array}{r}16 \\
7\end{array}$ & 21,9 & $\begin{array}{r}19, \\
3\end{array}$ \\
\hline
\end{tabular}

Source: built according to [18].

Consequently, the intensification of crop production is increasing, which in itself is not a negative fact, but the conclusion cannot be unequivocal, given the dynamics of the structure of expenditures on agricultural production in agribusinesses in Ukraine. The first positions in the total amount of material costs, which forms the cost of production, is steadily for the mineral fertilizers, which increased from $16.6 \%$ to $20.5 \%$ in the period from 2012 to 2016 , in the year 2017 they amounted to $12.3 \%$. Instead, the share of feed costs shows a steady reduction from $20.8 \%$ in 2012 to $10.3 \%$ in 2017 .

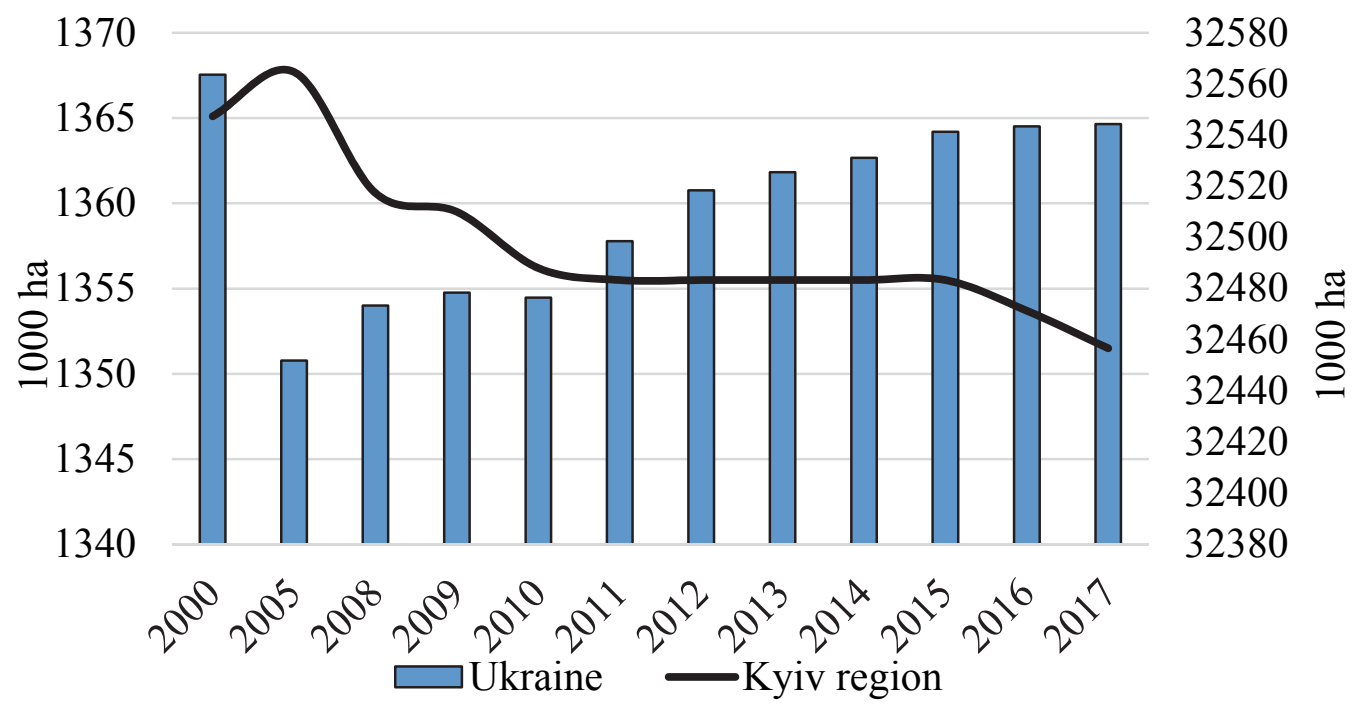

Fig. 2. Area of arable land, 1000 ha

Source: [18].

Similar tendencies are observed in the structure of the agri-enterprises expense for wages, which in 2012 amounted to $9.2 \%$, and in 2017 - they decreased to $5 \%$ and with amortization deductions, which decreased to 2017 by $4.7 \%$ of $5.3 \%$ in 2012 . There is also a reduction in the proportion of social contributions from $3.4 \%$ in 2012 to $1.2 \%$ in 2016 and in 2017 they were at $1.1 \%$.

The given information gives evidence to increase of economic efficiency of agricultural land use due to neglect of ecological and social components of social development. This is indirectly confirmed by the report of the Ministry of Agrarian Policy and Food of Ukraine, in which the Deputy Minister of the Ministry of Agrarian Policy stated: "... According to the results of January-June 2018 Ukrainian agricultural exports amounted to 8.6 billion dollars. USA. Total foreign trade turnover of agro-industrial complex 
reached 11.3 billion dollars. USA, which is by $3.5 \%$ more than in the same period last year and is $23 \%$ of the total foreign trade turnover of Ukraine." The above is a confirmation of the thesis that an increase in agricultural production profits is due to the depletion of agro-resource potential. This is confirmed by the results of soil surveys, which testify to the depletion of agro-resource potential of agricultural land and show deterioration of their qualitative condition. Thus, according to the results of the $X$ Agrochemistry Survey conducted in $2011-2015,57.5 \%$ of the agricultural land have been destroyed by erosion process and these processes are continuing [20].

The decisive reason on the deterioration of the agrochemical properties of the soil contributes due a rapid reduction in the amount of financing for the implementation of land conservation measures. There is a steady reduction in the volume of implementation of such measures as liming, which, for example, in 2015 made only $2.4 \%$ of the total area of acid soils in Ukraine from the minimum required $20 \%$ annually, and in the Kiev region, the volume of these works has been reduced from 5, 6 thousand hectares in 2011 to 0.8 thousand hectares in 2015 [20, p. 7]. As a result, removal of calcium by plant products and leaching from the soil profile (the process of decalcification) leads to the loss of the most valuable part of the soil - humus. In addition, according to national statistics, the construction of antierosion hydrotechnical structures has almost ceased (in 2010, built $8.5 \mathrm{~km}$, in $2015-0.2 \mathrm{~km}$ ), the use of degraded arable land has decreased from 1 thousand hectares in 2010 to 0.2 thousand hectares in 2015, implementation of reclamation from 0.5 thousand hectares in 2010 to 0.1 thousand hectares in 2015. And the financing of implementation of measures for the protection of land plots for 1991 - 2007 has decreased by 25 times [18]. As a result, about $50 \%$ of agricultural land was subjected to degradation processes. The first signs of imbalance display are arised in the form of a decrease in the content of organic matter in the soil, an increase in its acidity, dehumidification, increased erosion processes, salinization of soils, which ultimately leads to loss of soil fertility.

Thus, the land use organization of agro-industrial production needs to be reformed both for Ukraine as a whole and for the Kyiv region in particular, in order to ensure environmental efficiency, provided that economic indicators of economic activity are maintained. The organizational and economic structure of agricultural production processes requires the improvement of the institutional component in order to increase producers' responsibility for the level of agroecological safety of the territories, and above all those whose activities are oriented on the commodity crop production. One of the tasks of these changes should be the formation of the financial and economic dependence of the profits of agroentrepreneurs not only on the volumes of harvesting, but also on the quality of the harvested production and soil, which is acquired by agricultural land as a result of the introduction of agro-industrial activities. Institutional regulation of agricultural land use processes towards solving problems of ensuring an acceptable level of agroecological safety has a high potential in terms of creating a legal and organizational and economic environment in accordance with market principles. Among the priorities of these changes, focusing on the opinion of other researchers [15, p. 418; 6], it is possible to define:

- the development of environmental legislation in the direction of strengthening environmental restrictions and requirements with a clear regulation of environmental processes and, first of all, agricultural land use, taking into account the conditions for the introduction of free economic circulation of land plots;

- the orientation of production processes to the achievement of the framework of international standards of agricultural technologies, the strengthening of the landscape approach in the organization of land use processes and the provision of specified parameters of the quality of agricultural production, which creates the necessary prerequisites for the attraction of national products to operations in international markets;

- the formation of a system of financial and economic incentives and leverage in the transformation of tax, credit and pricing policies of resource conservation, the use of environmentally sound technology, the use of advanced technologies and materials; 
- ensuring the implementation of the environmental management system and audit with an assessment of the level of efficiency of production and sales of products at all hierarchical levels of management, taking into account the regional dimension.

The solution of this task requires improvement of the legislative framework. Until recently, only the draft State Target Program for the Development of the Agrarian Sector for the period up to 2021, designed not to mention the need for the restoration and preservation of agro-resource potential, has been worked out in Ukraine, but only one of the sub-clauses has declared intentions to implement measures to combat degradation of agricultural land, desertification and water and wind erosion [21]. Approximate amounts of financing of this program are declared at the level of more than 81 billion UAH, as sources of which almost $97 \%$ are proposed to consider the state budget, $2 \%$ - local budgets; the rest of the funding - at the expense of other sources of income. A significant source of local budget revenues is the payment for land (in the income structure it occupies $12.2 \%$ ), which is related to the property tax and is a component of local taxes. In the reporting period, local budgets received 18.2 billion UAH of land payment, which is $2.7 \%$ more than revenue for the same period last year. The budgets of regional territorial groups grew by $11.2 \%$ (UAH 204.7 million) [21]. But a simple declaration of the need for these types of activities is not enough. Now there is a need for the adoption of the State Program of use and protection of agricultural land resources with its extension at the regional level in the form of regional subprograms, which should include a set of scientifically grounded measures taking into account local soil and climatic conditions, ecological and economic features of agrarian production and, as a result, these should will support the economy development. The systematic continuation of such program activities should be the development of the planned implementation of a set of scientifically grounded land protection measures with the establishment of indicative terms for their implementation, the volume of the cost of work on their implementation, and the definition for the diversificated funding sources with the gradual increase of the role of local budgets.

Along with the introduction of administrative and territorial reform, it is necessary to emphasize the importance of intensifying the completion of land reform, and above all, the introduction of free economic conversion of agricultural plots. This will contribute to filling budgets of all levels, increasing the volume of working capital of agricultural producers through financial and economic instruments of pledge. The implementation of this instrument requires consideration of the essence of the pledge of agricultural land plots, the harmonization of different aspects of land, agrarian, civil-law relations. But here is appeared the national regulatory-legislative collision : the rental instruments which widely used in Ukraine for the agricultural production do not give the right to dispose of land as property. It is this circumstance that is a significant barrier to obtaining bank loans, since financial and credit institutions do not receive material support for issued borrowed funds. Today, farmers can borrow due a pledge of future harvests. Predicted potential profits from future harvests are very risky due to the existing natural and climatic and financial and economic conditions, due to the absence of a system for forecasting yields and prices for agricultural products in Ukraine, monitoring and forecasting of the state and conjuncture of foreign markets. High levels of risk are one of the reasons for high interest rates on bank loans, which increases the risk of bankruptcy for agricultural producers. High lending rates are not a typical situation for a country with a developed market economy. In particular, in the EU, compared to Ukraine's terms, the level of credit rates is quite acceptable and is 5 - $6 \%$ [14], and in the case of lending to the agro-industrial sector, these parameters are trying to reduce to $3 \%$. But the main reason for the obstacles is due to property rights. At the same time, the fact that according to Article 133, part 4 of the CCU [3], mortgage holders of agricultural land areas can be only banks. Accordingly, an agricultural producer who needs current working capital, cannot apply for a loan on the mortgage of a land plot, to financial-credit source.

\section{Conclusions}

It is proved that modern organizational and economic approaches to agricultural land use in Ukraine do not ensure its balanced state. The existence of an increase in profits from the production of 
commodity crop production due to the depletion of the agro-resource potential of the territories is statistically confirmed. The conceptual aspects of ensuring an acceptable level of agroecological safety of agricultural land use in the production of commercial crop production are determined. The role of local communities in solving this problem in the light of administrative reform in Ukraine is highlighted and the importance of introducing a free economic conversion of agricultural land plots is emphasized. It is shown the significance of institutional and economic levers in updating of organizational and economic conditions of economic activity that aimed at creating financial and economic responsibility of economic entities in the production of commodity crop production for the level of agrochemical parameters of the qualitative state of soils. This is an effective direction in ensuring the restoration and preservation of agroresource potential.

\section{Reference}

1. Butrym O. V. (Drebot O.I. Ed.). (2018). Teoretyko-metodologichni osnovy formuvannya vnutrishnogo vuglecevogo rynku $\mathrm{v}$ konteksti zbalansovanogo rozvytku agrosfery: monografiya. Kyiv: TOV «DIA». 360 p. [in Ukrainian].

2. Bystryakov I. K., Klynovyj D. V. (2015). Systemne vyznachennya ekonomichnoyi ocinky pryrodnogo bagatstva Ukrayiny. Visnyk Nacionalnoyi akademiyi nauk Ukrayiny. 8. pp. 49-57. [in Ukrainian].

3. Ivanov Yu. G., Kochurov B. I. (1987). Pryrodooxrannoe zonyrovanye terrytoryy admynystratyvnoj oblasty. Landshaftnbj analyz pryrodopolzovanyya., pp. 12-19.

4. Gajduczkyj I. P. (2014). Investuvannya nyzkovuglecevoyi ekonomiky: teoriya, metodologiya, praktyka: monografiya. Kyiv: TOV «Informacijni systemy», pp. 374. [in Ukrainian].

5. Gajduczkyj P.I., Sabluk P.T., Lupenko Yu.O. et al. (Gajduczkyj P.I. Ed.). (2005). Agrarna reforma v Ukrayini. K. : NNCz IAE. 424 p. [in Ukrainian].

6. Stupen M., Skorupska O. (2014). Ekonomichni aspekty racionalnogo zemlekorystuvannya silskogospodarskogo pryznachennya. Visnyk Lvivskogo nacionalnogo agrarnogo universytetu. Ser. Ekonomika APK. 21(1). pp. 389-395. [in Ukrainian].

7. Xloby'stov Ye. V., Zharova L. V. (2010). Problemy instytucionalizaciyi systemy racionalnogo pryrodokorystuvannya ta oxorony navkolyshnogo pryrodnogo seredovyshha /. Markety'ng i menedzhment innovacij. 2. pp. 206-214. [in Ukrainian].

8. Grassi G., M. Elzen, Andries F. et al. (2012). The role of the land use, land use change and forestry sector in achieving Annex I reduction pledges. Climatic Change. № 115. P. 873 - 881.

9. George Boody, Vondracek Bruce, David A. Andow, Krinke Mara, Westra John, Zimmerman Julie, Welle Patrick. (2005). Multifunctional Agriculture in the United States. BioScience 55(1), p. 27-38.

10. Nerbonne B.A., Vondracek B. (2001). Effects of local land use on physical habitat, benthic macroinvertebrates, and fish in the Whitewater River, Minnesota, USA. Environ Manage. Jul; 28 (1): 87 99.

11. Scherr, S. J, S. Shames and R. Friedman. (2013). Defining integrated landscape management for policy makers. Ecoagriculture Policy Focus. - 2016, №. 10. Washington, DC: EcoAgriculture Partners. $235 \mathrm{p}$.

12. Mainstreaming climate change into rural development policy post 2013. Ana Frelih-Larsen. Ecologic Institute: Science and Policy for a Sustainable World. Berlin, 2016. URL: http://www.ecologic.eu/10439 (date of the recent exploitation: 18.12.2018).

13. Dobryak D. S., Kuzin N. V. (2016). Udoskonalennya klasyfikaciyi procesiv, shho sprychynyayut degradaciyu zemelnyx ugid. Zbalansovane pry'rodokory'stuvannya. 1. pp. 106-111. [in Ukrainian].

14. Martyn A. (2011). Rehuliuvannia rynku zemel v Ukraini: [monohrafiia]. Kyiv: Ahrar Media Hrup. 252 p. [in Ukrainian].

15. Granovska L.M. (2009). Ekologo-zbalansovane pry'rodokory'stuvannya v umovax polifunkcional'nosti tery'torij. Xerson. 417 p. [in Ukrainian]. 
16. Yong Jiang_Stephen K. (2017). Swallow. Impact Fees Coupled With Conservation Payments to Sustain Ecosystem Structure: A Conceptual and Numerical Application at the Urban-Rural Fringe. Ecological Economics. p. 136-147.

17. Hrynova V.M., Shulha H.lu. (2010). Ekonomika pratsi ta sotsialno-trudovi vidnosyny: Navch. posib. Rekomendovano MON. K. 310 s. [in Ukrainian].

18. Roslynnytstvo Ukrainy 2017. Statystychnyi zbirnyk. Kyiv: Derzhavna sluzhba statystyky Ukrainy, 2018. 222 p. [in Ukrainian].

19. Silske hospodarstvo Ukrainy 2017. Statystychnyi zbirnyk. Kyiv: Derzhavna sluzhba statystyky Ukrainy, 2018. 245 p. [in Ukrainian].

20. Yatsuk I.P. (Ed.). (2017). Naukovi doslidzhennia $z$ monitorynhu ta obstezhennia silskohospodarskykh uhid Ukrainy za rezultatamy X turu (2011-2015 rr.) Kyiv: DU «Instytut okhorony gruntiv Ukrainy». 66 p. [in Ukrainian].

21. Pro vnesennia zmin do rozporiadzhennia Kabinetu Ministriv Ukrainy vid 30 hrudnia 2015 r. № 1437. Ofitsiinyi visnyk Ukrainy, 2016 r., № 24, st. 960. [in Ukrainian].

1. 